\title{
SZONDI LIPÓT SORSANALÍZISE
}

\section{GYÖNGYÖSINÉ KISS ENIKŐ}

Pécsi Tudományegyetem, Pszichológia Intézet, Személyiség-, Fejlődés- és Klinikai Pszichológiai Tanszék

E-mail: gyongy@btk.pte.hu

\begin{abstract}
A tanulmány Szondi Lipót sorsanalízisének szemléleti, elméleti alapjait mutatja be. Szondi sorsanalizisét az 1930-as években kezdte el kidolgozni, melyre elsödlegesen Freud pszichoanalizise és a korabeli orvosi-, genetikai, természettudományos ismeretek voltak nagy hatással.

Az elsö sorsanalitikus tanulmány 1937-ben jelent meg Hágában, melyben az elmélet megszületésének kiinduló koncepcióját követhetjük nyomon. Az alapkoncepció változása Szondi kényszerü emigrációja - 1944 - után a svájci pályaszakasz publikációiban jelenik meg. A szerzö a sorsanalizis olyan alapvetö fogalmait mutatja be, mint például a sors, az ösztön, ösztönfaktorok és -tendenciák, az én, a Pontifex oppositorum, mely fogalmak a magyarországi és svájci munkásság összegzéseként jelentek meg Szondinál.
\end{abstract}

Kulcsszavak: a sors fogalma, a sorsanalízis ösztönrendszere, az Én sorsanalitikus felfogása, a sorsanalizis emberképe

\section{A SORS FOGALMÁNAK JELENTÉSE A PSZICHOANALÍZISBEN ÉS A SORSANALÍZISBEN}

Freud pszichoanalízisében az egyén sorsa az ösztönök személyes konfliktusában formálódik, amire a felettes én és az én instanciája gyakorol befolyást. A speciális ösztönigények az én elhárító mechanizmusaival együttesen határozzák meg az egyén sorsának alakulását. A személyes sorsra meghatározó erővel bír az Ödipuszkomplexus, a kasztrációs szorongás, illetve a traumatikus pillanat elhárításának módja. A freudi pszichoanalízis ennek eredményeképpen a neurózist traumatikus eredetűnek véli, terápiás célja e trauma feldolgozására irányul.

Mindezek ellenére Freud többször is tesz utalást az átöröklés szerepére. Már az 1917-ben megjelent Vorlesungen zur Einführung in die Psychoanalyse címü kötetében (FrEUD, 1986) is elismeri az öröklés jelentőségét. A tünet képződésének útjai című előadásában az alkati tényezők befolyásáról a következőképpen ír: „... a gyermek- 
kornak a jelentösége kettős: egyrészt ekkor jelentkeztek először azok az ösztönirányok, amelyeket a gyermek veleszületett alkatában magával hozott, másrészt pedig külső hatások, véletlen élmények ekkor ébresztették fel, hozták müködésbe elöször egyéb ösztöneit. Azt hiszem, nem kétséges, hogy jogunk van erre a kettéosztásra. Hiszen a veleszületett alkat megnyilvánulása nem ütközik kritikai megfontolásba, az analitikus tapasztalat azonban egyenesen kényszerít annak feltételezésére, hogy a gyermekkor merö véletlen élményei libidórögzödéseket hagyhatnak hátra." (FREUD, 1986, 295.)

Az öröklés szerepét hangsúlyozza Freud $A$ befejezett és a vég nélküli analízis címü írásában is, ami 1937-ben jelent meg. Az analízis befejezhetőségéről így nyilatkozik: „A neurotikus zavarok etiológiája általában vegyes: vagy túl erös ösztönökröl van szó, melyek makacsul ellenszegülnek az én fegyelmezö erejének, vagy kisgyermek kori, tehát olyan korai traumák hatásáról, melyeken a még fejletlen én nem tudott úrrá lenni. Rendszerint e két tényezö, az alkati és az esetleges együttmüködéséröl van szó. Minél erösebb az elsö, annál nagyobb valószinüséggel vezet rögzödéshez és fejlödési zavarhoz egy trauma, minél súlyosabb a trauma, annál biztosabban fog megnyilvánulni az ártalom még normális ösztönállapotok mellett is. Kétségtelen, hogy az analizis számára sokkal kedvezöbb feltételt nyújt a traumatikus etiológia. Az analizis inkább a túlnyomórészt traumatikus esetekben fogja véghez vinni, ami egyáltalában hatalmában van, hogy a kora gyermekkor hiányos képlete helyére - hála az én megerösödésének - a teljeset helyezi. Csakis ilyen esetben beszélhetünk befejezett analizisröl.” Később Freud így folytatja: „A három tényező közül, melyet az analitikus terápia esélye szempontjából irányadóként fogadtunk el - a traumák hatása, az alkati ösztönerö és az én-változás -, itt csak a középsönek, az alkati ösztönerönek van jelentösége." (FREUD, 1981, 87-88.) A továbbiakban Freud az alkati ösztönerő fogalmát kitágítja, az alkati helyett aktuális ösztönerőrôl ír, mely magába foglalja a veleszületett és a későbbi életszakaszban spontán felerősödött ösztönerôt is.

Végül megemlíthetnénk Freud $A$ pszichoanalizis foglalata címü összegzését is, melyet halála előtt nem sokkal írt. A lelki készülék bemutatásakor a következőképpen fogalmaz: „A legrégibb lelki tartományt vagy hatóságot (instanciát) ösztön-énnek neveztük el. Az ösztön-én tartalmazza mindazt, ami öröklött, amit születésünkkor magunkkal hozunk, ami alkatilag van meghatározva. Tartalmazza tehát mindenekelött az ösztönöket, amelyek a testi szervezödésböl származnak és elsönek itt találnak, elöttünk ismeretlen formákban, pszichikus kifejezödésre." (FREUD, 1982, 410-411.)

A fentiek alapján láthatjuk, hogy Freud utolsó éveiben nem állt távol az örökletesség szerepének felülvizsgálatától a pszichoanalízis elméletét és gyakorlatát tekintve.

A sorskérdés problémája igazán nem merül fel Freud pszichológiájában, e nézőpont Szondi perspektívájában jelenik meg. A sors kérdése Szondi korai orvosi élményéhez kötődik. Pályája kezdetén észrevette azt a hasonlóságot, hogy a páciens és házastársának családjában hasonló megbetegedések fordulnak elő, amit Szondi nem a véletlennek tulajdonított (SZONDI, 1937). A felmerülő kérdés ezután így hangzott: mi irányítja az embert sorsdöntő választásaiban? A sorsdöntő választások közé sorolta Szondi a párválasztáson túl a barát-, pálya-, betegség- és halálnem-választást is. Munkája során több száz családfát készített több ezer rokon adatait összegyüjtve, hogy megtudja, a magyarázat miben rejlik. Végül arra a konklúzióra jutott, hogy a tudattalan ősi ösztönerők választanak bennünk vagy általunk. 
A választást irányító ösztönerők forrásai pedig a gének. Vagyis a gének közvetítésén keresztül őseink akarata érvényesül abban, hogy milyen barátot, házastársat, pályát választunk, milyen betegségben betegszünk s majdan halunk meg. A sorsanalízis szemléletében 1943-ban a sors kérdése a következőképpen hangzik. Az ember nem a véletlen, hanem „...egyéni „életterve« szerint él, cselekszik, választ barátot, pályát, élettársat, szerelmest; eszerint a terv szerint betegszik és hal meg. Az ember életében határozott terv vonul végig, és ez magyarázza, hogy az ember életpályája részeiben összefüggö, teruszerüen lefektetett egész, akár valamilyen eposz vagy regény. A sorsanalizis célja kikutatni az egyes ember sorsában azt a tervet, mely életét a születéstöl a halálig egésszé formálja." (SzONDI, 1943a, 5.)

Szondi sorsanalitikus tudományos tevékenységét két fô periódusra bonthatjuk, 1936-tól az 1944-es emigrációig a magyarországi periódusról beszélhetünk, míg 1986-ban bekövetkezett haláláig a svájci pályaszakaszt említhetjük. E két pályaszakasz felfogása különbözik az emberi sors felfogásában, ami igazából hangsúlyeltolódást jelent. Az ún. óanankológiai periódusban, 1944-ig elsősorban a sors kényszerító erejét írja le Szondi, ami közvetlen összefüggésben van az elmélet megszületésének hátterével. Szondit 1927-ben nevezték ki a Magyar Királyi Állami Gyógypedagógiai Tanárképző Főiskolán számára alapított Kórtani és Gyógytani Laboratórium vezető főorvosává és egyben az élet- és kórtan előadó tanárává. 1941-ig dolgozhatott itt, amikor a zsidótörvények bevezetése miatt megfosztották állásától. Balázs Péter (pszichológus, 1939-ben Brazíliába vándorolt ki, a Rio Grande-i katolikus egyetem pszichológia professzora volt) visszaemlékezése szerint Szondi a tesztképekkel már 1932-1937 között foglalkozott. Szondi tesztje és elmélete alapját a korabeli genetika nyújtotta, a fogyatékos gyermekek vizsgálatában az örökléstani tényezők, a családfakészítés fontos tapasztalati bázist jelentettek. Feltehetőleg Szondi korai személyes élményei, melyeket később kulcsélményekként határoz meg szakmai önéletrajzi írásaiban (SzONDI, 1999), valamint empirikus tapasztalatai együttesen vezették a sorsanalízis elméletének kialakításához.

Az óanankológiai megközelítés tehát a sorsot a családi öröklöttség, a vérrokoni kötelékek kényszerén belül írja le (vö. SzONDI, 1943a). Szonditól két könyv jelent meg ebben a periódusban, a származása miatti diszkrimináció következtében mindkettő külföldön. Első sorsanalitikus kötete az Analysis of Marriages 1937-ben Hollandiában jelent meg Révész Gézának köszönhetően, Schicksalsanalyse kötete pedig 1944-ben Svájcban. A Schicksalsanalyse kötet alcíme jellemzően mutatja be a kutatás akkori súlypontját: Genetic des Schiksals - vagyis a „sors genetikája”. Szondi későbbi interjúiban is szívesen definiálta úgy sorstanát, hogy az nem más, mint a genetika bevezetése a pszichoanalízisbe (Forgács Péter interjúja Szondi Lipóttal. Balázs Béla Filmstúdió, 1984).

A Schicksalsanalyse kötetben Szondi a szülők (familiáris ősök) által átörökített kényszer- és öröklött sorsformák leírásával foglalkozik, melyek az élet különböző területein nyilvánulnak meg. Vitathatatlan tehát erre a periódusra vonatkozóan a kényszer és az öröklöttség hangsúlya, ennek ellenére ekkor sem feledkezik meg Szondi a választás lehetőségérôl. Még ekkor bevezette sorstanába az irányítható fatalizmus fogalmát: „... a természet keze pontosan körülhatárolja az ember egyéni sorsterét, ámde az egyén génikusan körülhatárolt sorsterében tudatosan és szabadon választhatja 
meg azokat az életutakat és tárgyakat, melyeken ösi ösztönszü̈sségleteit egyéni módon elégitheti ki... Ezért beszél a sorsanalizis irányítható fatalizmusról. A sorsanalizis az ösztöngének mellett sorsunkat irányító hatalmakként tiszteli az állásfoglaló Ént és a szellemet. Az Én az a híd, mely az animális és bestiális ösztönöket a szellemmel köti össze. A szellem pedig az a transzcendens instancia, mely az egyéni Én közvetítésével humán jelleget és humanista menetirányt szab ösi ösztöntörekvéseinknek." (SzONDI, 1943a, 8.) A szocializáció, szublimáció, humanizáció mutatja az emberré válás útját.

Ez a gondolat már továbbvezet a svájci periódus újanankológiai sorsfelfogásához. Szondi nem tagadja meg korábbi tanait, hanem a kényszersors fogalmát kiegészíti a választott sors lehetőségével. Az egyén számtalan egzisztencialehetőséggel rendelkezik, az Én tudatosan, szabadon dönthet egyik vagy másik egzisztencialehetőség választása mellett. Ekképp életének minőségét tudatosan képes irányítani. Az Én által történő sorsválasztással kapcsolatos elméletét Szondi Ich-Analyse (1956) címü kötetében publikálta, az elmélethez kötődő gyakorlatot a Schicksalsanalytische Therapie (1963) címü könyvében írta meg. Az újanankológiai fordulat hozta meg a sorsanalitikus terápia mint technika kialakítását, vagyis annak lehetôségét, hogy a kényszersorsát élő ember az Én segítségével eljuthasson a szabadon megválasztott sorshoz.

A sorsanalízis a tudattalan genetikáját próbálja megragadni - legalábbis familiáris szinten. A sorsanalízis elmélete és gyakorlati terápiája Szondi szerint hidat teremt a mélylélektan három irányzata között - melyhez Freud pszichoanalízisét és Jung analitikus pszichológiáját sorolja. Mindhárom irányzat megegyezik abban, hogy a freudi felfedezésből, a tudattalanból indul ki, különbségük pedig abban mutatkozik meg, hogy a léleknek más és más rétegét veszik nagyító alá. „A lélek ontológiája, genealógiája és archeológiája együtt adják, illetve adhatják meg a mélypszichológia globalitását. Csak e három réteg önálló és összefüggö kutatásától várható a lélek struktúrájáról és müködéséröl hirt adó »egész lélek-kép «". Arra a kérdésre, hogy a három irányzat miért dolgozik három különböző elmélettel, Szondi így válaszol: „A nap fénysugarai az óceánnak csak a legfelsö rétegébe tudnak behatolni. A sötétség a tenger mélyén annál elviselhetetlenebb, minél mélyebb rétegekbe ereszkedik alá. Ezért gondoskodott a természet arról, hogy az átláthatatlan óceáni sötétség különbözö mélységeiben élö tengeri lények mindegyike külön-külön árassza ki testéböl azt a magán-fényt, amely biztosítja számukra a tenger különbözö mélységeiben az önálló tájékozódást. Nos: a mélypszichológia három irányzatának is azért van szüksége három önálló elméletre - a hasonlatnál maradva -, három magánfényforrásra, mert mindegyik a lélek tengerének más és más rétegében dolgozik, ahová a fölötte és alatta lévö rétegben dolgozók elméletének fénysugarai alig tudnak behatolni." (SZONDI, 1943a, 308-309.)

Freud pszichoanalízisében a szimptómától vezet az út a tudattalanba az ösztönélethez, a szexualitáshoz. Freud szerint a szimptóma jele és egyben helyettesítője egy elmaradt ösztönszükségletnek, egy elfojtási folyamat eredménye. A pszichoanalízis a tudattalan személyes síkját szólaltatta meg a szimptómák segítségével. Jung analitikus pszichológiájában a kollektív tudattalan rétegében a szimbólumok archetipikus természetét írta le. Szondi sorsanalízisében a familiáris ősök törekvéseinek átöröklésével a családi tudattalan rétegét tárja fel, ami az ember sorsválasztásaiban nyilvánul meg. 
A szimptóma, a szimbólum és a választás nyelve a tudattalan három különböző rétegét világítja meg, e három réteg azonban csakis kontinuitásában, globalitásában fogható fel (SZONDI, 1996).

\section{A SORSANALÍZIS ÖSZTÖNFOGALMA ÉS ÖSZTÖNRENDSZERE}

A sorsanalízis ösztönrendszere arra az elgondolásra épül, hogy az ösztönforrás és az ösztönenergia minősége az ösztöntan szempontjából alapvető tényezők. A forrás és az energia közötti összefüggés abban nyilvánul meg, hogy specifikus ösztönenergia csak specifikus ösztönforrásból fakadhat. Ha az emberi ösztönrendszer általános alapjait keressük, Szondi szerint először meg kell határoznunk azt az alapot, mely valamennyi ösztönféleség közös természetét írja le, majd meg kell keresni azokat az elkülönítő jegyeket, melyek alapján az egyes ösztöntényezők egymástól jól elhatárolhatóak.

A sorsanalízis a közös biológiai alapot a génekben találta meg. Az ösztön közös természetét a gének közös természete határozza meg, mely minden emberben hasonló módon működik. Az ösztöntan génelmélete felteszi, hogy az ösztönös jelenségek specifikus gének által - ún. ösztöngének által - meghatározott lelki reakciók. Az ösztönös reakciót meghatározó gének mellett egyéb géneket is találhatunk, melyek például testi vagy mentális reakciókat határoznak meg. Minden gén sajátja, hogy egy hajdani, ôsi állapotot törekszik visszaállítani az utódban, s ha az ösztönök géneredetűek, az ösztönökben is közös az a törekvés, hogy egy hajdani állapotot valósítsanak meg újra. Szondi az ösztönök génelméletéből fakadóan kifejti, hogy annyiféle ösztöntörekvésről beszélhetünk, ahány ösztönös reakciót meghatározó gén létezik. Ezen a ponton tehát nem ért egyet Freud dualizmusával, aki két ösztönfajtát különböztet meg: az önfenntartó és a fajfenntartó ösztönöket, illetve később az élet- és halálösztönt.

A sorsanalízis genetikus elméletében kifejti, hogy az emberek többsége a legtöbb ösztönszükséglet tekintetében heterozigóta. Ez azt jelenti, hogy az egyén egy bizonyos ösztönszükségletét tekintve más hajlamokat örökölt az apától, mint az anyától. Ebből a tényből következik, hogy a legtöbb emberben az ösztönszükségletek legtöbbjét olyan allél-génpár dönti el, melynek két homológ génje két egymástól eltérő, esetleg egymással gyökeresen eltérő törekvést határoz meg. Mivel az egyén az adott ösztönszükségletet tekintve heterozigóta - a két eltérő törekvés ösztönellentétpárt hoz létre. Az ösztön-ellentétpár lélektanilag nem más, mint az ösztönszükségletet génikusan meghatározó allél-génpár ösztönpszichológiai kifejezése.

Az allél-génpárok két homológ génje között fennálló ellentét az ösztönpárok eredetének csak az egyik formáját írják le. Az elmebetegségek örökléstani vizsgálatára alapozva Szondi utal az öröklődés dimer, illetve polimer lehetőségére is, amikor egy ösztönt legalább két vagy több génpár határoz meg, melyek örökléstanilag egymástól függetlenek, de a kritikus ösztön megnyilvánulását közösen hozzák létre.

Az ösztön feszítő ereje a génelmélet alapján a gének egymás közti viszonyától függ. Az ösztönszükségleteket specifikusan meghatározó allél-génpár két homológ 
génje között fennálló különbség nagysága határozza meg valamely ösztön feszítő erejét. Másképp megfogalmazva, a domináns és a recesszív gén közötti küzdelemtől függ valamely ösztönszükséglet feszítő ereje.

SzONDI (1960) a sorsanalízis ösztönkritériumait az alábbi öt pontban foglalta össze:

1. Az ösztönök génikus eredetűek.

2. Az ösztöntörekvések és ösztönszükségletek polaritása. E megállapítás szerint csakis oly jelenségeket nevezhetünk ösztönös jelenségeknek, amelyek a léleknek ugyanazon megjelenési területén egymással ellentétes vagy mennyiségben különböző törekvések, illetve szükségletek párba állását mutatják. Ezen ösztöntörekvések egy része humán, más része pedig nem humán természetű. A legtöbb ember heterozigóta természetéből fakad, hogy a humán és nem humán ösztöntörekvések vegyesen fordulnak elő az egyénnél. Amennyiben ez a strukturális polaritás hiányozna, nem beszélhetnénk igazán dinamikus ösztönökről sem.

3. Az ösztöndinamizmus vagy ösztönfeszültség feltétele, ami a fent említett ösztöntörekvések és szükségletek polaritásából következik, az ellentétes erők harcából. E feszültség a génelmélet szerint az apriori génküzdelem képviselöje a lélekben.

4. Az élet- és kórlélektani kritérium: csak oly jelenségeket nevezhetünk ösztönös folyamatoknak, melyek kivétel nélkül minden emberben megtalálhatóak (ez az élettani kritérium), másrészt pedig az emberek egy kisebb részénél ezek oly szélsőséges fokban mutatkoznak meg, hogy önálló ösztönbetegség felállítását tették szükségessé (kórélettani kritérium). Szondi kifejti, hogy az elmebetegek elsődlegesen ösztönbetegek, a személyiség és az Én szétesését, az ezzel járó mentális zavarokat következményes, vagy más szóval reakciós képződményként fogja fel. A sorsanalízis átveszi a korabeli pszichiátriai örökléstan eredményeit, melyek az elmebetegségek négy önálló csoportját állapították meg: szkizoform öröklődési kör (katatónia, paranoia); cirkuláris vagy mániako-depresszív öröklődési kör; epileptiform vagy paroxizmális öröklődési kör; szexuális ösztönbetegek köre (homoszexualitás, szadizmus). A betegségkörök elhatárolása a normától nem éles, ami azt jelenti, hogy az elmebetegeknél megtalált ösztönszükségletek egytől egyig megtalálhatóak a nem elmebeteg személyeknél is, részben az egyéni ösztönfejlődés egy korábbi fokán, részben később az eredeti ösztöncéljuktól eltérített, denaturált, szocializált vagy szublimált formában.

5. Végül az önálló mendelezés kritériuma, ami feltételezi, hogy a kritikus ösztönszükséglet önálló öröklődése kimutatható.

A sorsanalízis ösztönrendszere a korábban említett négy öröklődési körre épül, ennek alapján a sorsanalízis elmélete négy ösztönkört ír le: szexuális, paroxizmális, szkizoform és cirkuláris ösztönkört. Az ösztönkör fogalma egybeesik az ösztönvektor fogalmával, ami azt is jelenti, hogy egy-egy ösztönvektor két ösztönfaktor- 
ból áll. A két ösztönfaktor azt mutatja meg, hogy az ösztönvektor mindegyike egy ösztönszükségleti ellentétpárt tartalmaz. Az ösztönfaktor ugyanakkor önmagában is kettős tendenciát hordoz, melyek az apai és az anyai homológ gén törekvését fejezik ki. A szexuális ösztönkör például két ösztönfaktorra (egymással ellentétes ösztönszükségletre) bomlik, a homoszexualitásra (nemi gyöngédség) és szadizmusra (nemi erőszakosság); melyek további két-két tendenciára eshetnek szét, a hfaktornál a konkrét személyre irányuló nemi gyöngédségre, illetve az emberiségre irányuló, kollektív emberszeretetre. A szadizmus faktora két ellentétes tendenciájában az agresszióra, illetve a mazochizmusra bomlik tovább. Az ösztöntörekvés fogalma Szondinál az allél-génpárnak csak egyik génje (az anyai vagy az apai gén) által meghatározott ösztöntani fogalom.

Az ösztönfaktorokat az ösztönélet radikáléinak is tekinthetjük. Az ösztönfaktorok tulajdonságai közé tartozik azok változatos megjelenési formája, melyet az egyes ösztönfaktorok sorslehetőségeinek (egzisztencialehetőségeinek) nevez a sorsanalízis. E tényből következik, hogy az ember nem egy sorssal, hanem számtalan sorslehetőséggel rendelkezik. A nyolc faktor sorslehetôségei eredeztethetőek a filogenetikus törzsfejlődés ősi formáiból (kivéve a szkizoform vagy más szóval az énes ösztönt); ugyanakkor minden faktor megfeleltethetô egy kora gyermekkori megjelenési formával; rendelkezik karakterformáló hatékonysággal; speciális foglalkozási körrel, ami a szociális körhöz való tartozást is megmutatja; továbbá a faktorok sajátos tünetegyüttessel is rendelkeznek. ${ }^{1}$

Az ösztönfaktorok és ösztönkörök azonban nem egymástól függetlenül fejtik ki hatásukat, hanem a fenomenológiai megjelenésben már egymással kölcsönhatásba lépve nyilvánulnak meg.

\section{AZ EMBER ÖSZTÖN-LINNAEUSA}

Szondi természettudományos mentalitása a sorsanalízis génelmélete mellett az ember általános ösztönrendszerének leírásában, más szóval az ember „ösztönlinnaeusának" felállításában is megmutatkozik.

Szondi tesztjét és a teszt által alkalmazott módszert az első időszakban kísérleti ösztönészlelésnek, illetve kísérleti ösztöndiagnosztikának nevezte el. E kifejezések jól mutatják a teszt megszületésének elméleti hátterét, valamint azt is, hogy Szondi milyen célból alkotta meg magát a tesztet. Szondi úgy gondolta, hogy a kísérleti ösztöndiagnosztika elméleti és tapasztalati alapon képes egy ún. ösztön-linnaeus megszerkesztésére, melynek rendszerében pontosan meghatározható minden embernek mind a nyílt, manifeszt, mind a lappangó, latens ösztön- és jellemsorsa. Az egyén meghatározására szolgáló ösztönrendszert azért nevezte el linnaeusnak, mert a botanikus Linnéhez (latinul: Linnaeus) hasonlóan Szondi is az ösztönök látható megnyilatkozásai és a kísérletben láthatóvá tett „láthatatlan gyökerei” alapján határozza meg, hogy az egyén milyen család leszármazottja, melyek ösztönéle-

\footnotetext{
1 Szondi részletes ösztönpatológiáját részleteiben nem tudjuk bemutatni, ezzel kapcsolatosan lásd: SZONDI (1960), SZONDI (1952), magyarul LuKÁCS (1996).
} 
tének és jellemének nyílt, látható megnyilatkozásai és milyen sorslehetőségek várnak rá a jövőben. Vagyis Szondi célja, hogy a növények rendszertanához hasonlóan felállítsa az ember ösztön-rendszertanát (SzONDI, 1942). A cél megfogalmazása a mai pszichológia számára meglepő, mégis a teszt mennyiségi indexeinek kiszámítása, a teszt értelmezésének az ún. mennyiségi módszere ennek alapján született meg.

Szondi elhatárolja magát a korabeli alkattanok, tipológiák pszichológiájától, élesen bírálva azok hibáit. A kretschmeri kórlélektani diagnosztika és jellemtipológia téves kiindulópontja, hogy kizárólag a nyílt, látható, manifeszt tünetekre építi fel a betegségek diagnózisát és a jellem tipológiáját. A kísérleti ösztöndiagnosztika szakít ezzel a felfogásmóddal, az „ösztönlinnaeus” a betegségformák mögött, a lélek mélyén lappangó láthatatlan ösztönszükségleteknek nagyobb jelentőséget tulajdonít, mint a nyílt klinikai vagy jellemtani tüneteknek.

A sorsanalízis szerint az ember sorsát elsődlegesen a lappangó, latens gének, a lappangó ösztöngénekbobl kiáramló és biológiailag elnyomott szükségletek irányítják. A sorspszichológia a lappangó és nyílt ösztönszükségletek alapján állítja fel az egyén sorsdiagnózisát és sorsprognózisát.

A kísérleti ösztöndiagnosztika a következőképpen definiálta önmagát: „...a neurózisok, elmebajok társadalomellenes (antiszociális) és társas értékü (szociális) jellemtípusok mögött nem mentális, nem racionális, nem is viselkedési és magatartási jelenségek után kutat, hanem elsősorban: a latencia miatt dinamikus, irracionális folyamatokat igyekszik láthatóvá tenni. Ezt azért teszi, mert azt vallja, hogy a különbözö neurózisok, pszichózisok és jellemtípusok elsősorban láthatatlan ösztöngyökereikben térnek el egymástól."

A kísérleti ösztöndiagnosztika „még a mentális folyamatokat, tehát az elmebajokat, szellemi képességeket és gondolkodási típusokat is úgy vizsgálja, hogy megkeresi bennük az »esztelen « és láthatatlan, irracionális ösztöngyökereket, melyekröl tudjuk, hogy hatékonyan áramlanak be a gondolkodás folyamataiba... a kisérleti ösztöndiagnosztika az irracionális ösztönök nyillt tüneteinél és látható jegyeinél nagyobb jelentöséget tulajdonit a "láthatatlan lappangó ösztönszükségleteknek. Ezért épültek fel a kisérleti ösztöndiagnosztika és annak alkalmazott részei, így a kórlélektani diagnosztika, a sorsanalitikus jellemtan, a sorsanalitikus betegség-és jellemprognosztika elsösorban a különbözö ösztönszükségletek latenciáján. A kisérleti ösztöndiagnosztika végsö célja éppen az egyénileg különbözö ösztön-latenciák láthatóvá tétele a kisérletben." (SZONDI, 1942, 2-3.)

A kísérleti ösztöndiagnosztika (mai megnevezésében Szondi-teszt) az ösztönlatenciák meghatározásának kísérleti módszerét vezette be a diagnosztikába. Az ösztön-linnaeus módszere lényegében nem más, mint a manifeszt és latens részösztönök integrációja. Az ösztön-linnaeus tapasztalati ösztönrendszere alapján az egyén sorslehetőségei megállapíthatóvá válnak.

\section{A KÍSÉRLETI ÖSZTÖNDIAGNOSZTIKA EREDMÉNYEINEK KÉT TOVÁBBI ÉRTELMEZÉSI LEHETŐSÉGE: A SZÉL-KÖZÉP ÉS AZ ELŐTÉR-HÁTTÉR}

A szél-közép értelmezési lehetősége a négy ösztönkör funkcionális egységén alapul. A „szél” elnevezés arra utal, hogy a tesztprofilon ábrázolt két széli ösztönkör- 
ről van itt szó: a szexualitás és a cirkuláris vagy más szóval a kapcsolati ösztönkör tartozik ide. A „közép” ezzel szemben a tesztprofilon középütt elhelyezkedő ösztönköröket foglalja magába: a meglepési vagy paroxizmális és a szkizoform vagy énes ösztönkört.

A szél-közép dialektika mutatja meg, hogy a személy az „ösztönvészt” milyen módon hárítja el. Ösztönvész akkor jelentkezik, ha egy addig leszorított ösztönigény felszabadul, vagy ha egy életfontosságú ösztönigény törekvése kihull az ösztönigények közül. Leggyakrabban az ösztönvész a széli ösztönkörök részéről fenyeget (szexuális és kapcsolati ösztönkörök), de előfordulhat a közép (paroxizmális és énes ösztönkör) ösztönbázisa miatt is. Az élet kezdetén a közép még csak funkcionális lehetőséget jelent, annak a lehetőségét, hogy az egyén később az élet során a széli ösztönökkel szemben állást foglalhasson. Az, hogy a közép - vagy a cenzúra - a szociális alkalmazkodás során a szociálisan pozitív vagy a szociálisan negatív irányt építi be állásfoglalásába, elsősorban a környezeten múlik. A miliő, a jó és a rossz példaképek, a nevelés, a vallás a személyiségfejlődés folyamatában együttesen adhatják meg a közép cenzúrarendszerének az erejét, minőségét. A közép szociálpozitív törekvéseinek erejét mutatja a „középen” a belső, etikus igazságérzet megjelenése a gyilkos érzelmű Káinnal és agresszióval szemben; a morális szégyen cenzúrája, ami lehetővé teszi a másokhoz való érzelmi-indulati alkalmazkodásunkat; a realisztikus érdeklődéscenzúra vagy racionális értelem; végül a szellemi ideál cenzúrája, ami az én-ideálon alapul és az ösztönvész szublimációs megoldási lehetőségein. Ha a „középen” a szociálpozitív cenzúra működik, a szélen is a szociálpozitív törekvések valósulnak meg, annak ellenére, hogy ez magában hordozhat szociálnegatív (animális, örömkereső) vagy egymással szembenálló szociálpozitív humán törekvéseket is.

Amennyiben a társadalmi alkalmazkodás folyamatában a középen a szociálnegatív törekvések valósulnak meg, megjelenik a gonoszságra való hajlam, a durva indulatok felduzzasztása, düh, gyülölet, harag, irigység, féltékenység; a szemérmetlen érvényesítési törekvés; a hatalom- és birtoklási vágy, az önszeretet; hajlam a projekcióra, mások vádolására, a saját felelősség elhárítására (SzONDI, 1996).

Szondi cenzúrarendszere (Freud felettes énjéhez hasonlóan) az én működésére van hatással. Az én az ösztönigényekkel szemben állást foglalhat pozitív vagy negatív módon, helyeselheti az ösztönigény beteljesülését vagy tagadhatja azt.

A „közép” és „szél” dialektikáján túl a tesztben további értelmezési lehetőséget nyújt az „előtér” és a „háttér” vizsgálata. Az előtér és a háttér értelmezése az ösztönrendszer poláris ellentétességén alapul. Szondi sorspszichológiájában 16 ösztöntörekvés küzd egymással a megvalósulásért. Természetesen ezek az ösztöntörekvések a valóságban nem tudnak egyszerre megvalósulni, a poláris ellentétesség alapján nyolc ösztöntörekvés juthat egy bizonyos időpontban a felszínre. A manifesztálódott ösztöntörekvések jelzik azok pillanatnyi döntő erejét, ezek a kísérleti ösztöndiagnosztika során az előtérben fognak megjelenni. A háttérben maradt ösztöntörekvéseket az én az adott pillanatban elutasítja, de a környezeti befolyás hatására ezek megerősödhetnek és egy későbbi időpontban felszínre törhetnek. A háttérben lévő tendenciák később tehát az előtérbe léphetnek és egyúttal a korábbi előtér-tendenciát a háttérbe tolhatják. Szondi az ösztönök színpadát a forgó- 
színpadhoz hasonlítja, melynek egyszer az egyik, máskor a másik oldala mutatkozik meg. Egyénenként különböző e színpad forgathatósága, melyet az én állásfoglalása irányít - azonban a túl könnyű és a túl nehéz forgathatóság egyaránt patológiához vezet. Az én relatív autonómiája és ereje segíti a forgószínpad megfeleló múködését. Az én állásfoglalásának megváltozását külső és belsô tényezők egyaránt okozhatják, a belső tényezők elsősorban a poláris ösztönstruktúrán alapulnak,

a külső tényezők pedig lehetnek traumatikus élmények, sokkhatások.

A háttérben lévő tendenciák csak relatíve veszítik el megvalósulási képességüket, ugyanis megjelennek az egyén vágyaiban, gondolat-, álom- és fantáziavilágában, hobbijában és szenvedélyeiben. A háttér játszik szerepet a karakter kialakításában, a szimptómaképzésben és minden választási folyamatban (szerelmi választásban, továbbá barát-, foglalkozás-, betegség- és halálnem-választásban).

Habár az én megtagadja a háttérbe szorult tendenciák manifesztálódását, azok a háttérben folyamatosan múködnek, és az egyén számára észrevétlen módon alakítják a sorsát. Az előtér és háttér szimultán működése hozza létre azt a dialektikát, amely a legfontosabb ösztönrugó a lélek dinamikájában.

\section{AZ ÉN GENEZISE ÉS MÜKÖDÉSE A SORSANALÍZISBEN}

\section{Az Én eredete és struktúrája}

Szondi az Én eredetére vonatkozó elképzeléseit még 1943-ban publikálta sokszorosított kézirat formájában (SzONDI, 1943c). Az e helyen megjelenő koncepció azonban nem így vált késôbb a Svájcban megjelenő Ich-Analyse című (SzONDI, 1956) kötetének részévé, az „eredet” és a „struktúra” leírása helyébe a későbbi kötetben az Én múködésének funkcionális leírása lépett. Feltehetőleg a több problémás feltételezést tartalmazó Én-tant Szondi újszerűbb „nyelvezetre” fordította át, aminek alapja a funkció megragadása lett. (Nem hagyhatjuk figyelmen kívül azt a tényt, hogy ugyanebben az időszakban jelentkezik a pszichoanalízis Énpszichológiai fordulata, ahol HARTMANN (1939) és HARTMANN, KRIS és LOEWENSTEIN publikációi nyomán az Én különböző funkciói kerülnek leírásra.) A sorsanalízis elméletében az integrált Én-működés négy elemi Én-funkció (projekció, infláció, introjekció és negáció) zavartalan működéséből jön létre. Szondi Ich-Analyse (1939) című kötetében egyúttal az Én fogalmát filozófiailag kitágítja, mely magasabb instancia a Pontifex oppositorum elnevezést kapja. A sorsanalízis elmélettörténetének e két különböző állomását két alfejezetben mutatjuk be.

SzONDI (1943c) kéziratában az Én genezisét örökléstani alapokra helyezte. Az Én kialakítója egy ösztön, amit a kísérleti ösztönészlelés során a szkizoform ösztönkörben olvashatunk le. Az Én-t eredetileg az én-kitágító ösztön teremti meg, mivel ez hozza létre az én-tudatot, azaz a szükségleti tudatot. Ezzel az egodiasztolikus (p) ösztönszükséglettel szemben az egoszisztolikus (k) ösztönténye- 
ző az állásfoglaló Én-t teremti meg. Az állásfoglaló Én funkciója, hogy döntsön a tudatossá vált ösztönigények sorsáról.

A sorsanalízis szerint a tudat két részből áll: az érzékelési és a szükségleti tudatból. Az érzékelési tudatot az érzékelés népesíti be szemléletekkel, a szükségleti tudatot pedig a tudattalanból kitörő génikus ösztönszükségletek töltik be ösztönigényekkel, ösztöntörekvésekkel. Szondi egoidoknak nevezi azokat a géneket, amelyek a családi tudattalanból származnak, és ha manifesztálódni tudnak, az Én integráns részévé válnak. A tudatos és tudattalan (a manifesztálódott, illetve a lappangó állapotba került és legyőzött) egoidok, vagyis a homológ allél-egoidok között a kapcsolat nem szakad meg a későbbiekben sem, az egész élet során zajlik a génikus küzdelem a manifesztációért. (Az öntudat ebből kifolyólag a sorstanban nem más, mint a tudatos és tudattalan egoidok küzdelmének, illetőleg kölcsönös kapcsolatának képviselöje a lélekben.) Az Én-t végül is a győztes egoidok integrálódása hozza létre, a legyőzött egoidok pedig latensek maradnak. A sorspszichológiában a tudat a már manifesztálódott génikus ösztöntörekvések tartományát jelenti, míg a tudattalan a domináns gének által elnyomott, lappangó, latens génikus szükségletek birodalmát. A latens egoidok a genotipikus megnyilvánulásról lemondanak, ehelyett a tudattalanból irányítják az egyén ösztönös választásait, amit Szondi genotropikus megnyilvánulásnak nevez, a folyamatot magát pedig genotropizmusnak. A genotropizmus a családi tudattalan fö müködési területe, ami a tudattalan választást jelenti az élet különböző (a már említett barát-, szerelmi, foglalkozás-, betegség-, halálnemválasztás stb.) területein.

A korábbiakban jeleztük már az Én két alapfunkcióját: az egodiasztolét és az egoszisztolét. A sorsanalízis szerint a tudattalanban az elnyomott géneknek két csoportja található: az első csoport olyan egoidokból áll, amelyek még sohasem manifesztálódtak, de manifesztálódni akarnak. A tudattalannak ezt a részét nevezi Szondi képletesen „a néma ősök várócsarnokának” (p-). A második csoportot a működésétől megfosztott egoidok alkotják, ez a tartály a „pórul járt ősök tömlöce” (k-). A két tábor állandóan veszélyezteti az Én állandóságát, integritását azáltal, hogy az első csoport az Én - a szükségleti tudat - kitágítására törekszik; a második csoport az ítélô, állásfoglaló Én megváltoztatására tör. Az egodiasztole és az egoszisztole az Én-élet állandó működésben lévő két alapfolyamata.

Az Én-működés sémáját (SzONDI, 1943c, 247) az 1. ábrán mutatjuk be az ösztönprofilon történő elhelyezkedésében. Az ábrán látható négy tartomány jelentése:

I. (p-): a még nem manifesztálódott egoidok tartálya, az ősök várócsarnoka.

II. $(\mathrm{p}+)$ : a tudatba betört premanifeszt egoidok tartálya, a szükségleti tudat, a tudatos Én képe a profilon.

III. (k+): a már manifesztálódott egoidokból kialakult és a merev éntudatzárt alkotó egoidok tartálya. Az ítélő, állásfoglaló Én, a szabad akarat képe a profilon.

$I V$. (k-): a külvilág és a nevelés hatására elfojtott egoidok tartálya, az elfojtás képe a profilon. „A póruljárt ősök tömlöce”. Jelzi az adaptációt. 
Az ábrán lévő nyíl mutatja az egoidszükségletek útját a családi tudattalanból (I.) a szükségleti tudaton át (II.) az énzárig (III.) és onnan az elfojtásig, az alkalmazkodásig (IV.).

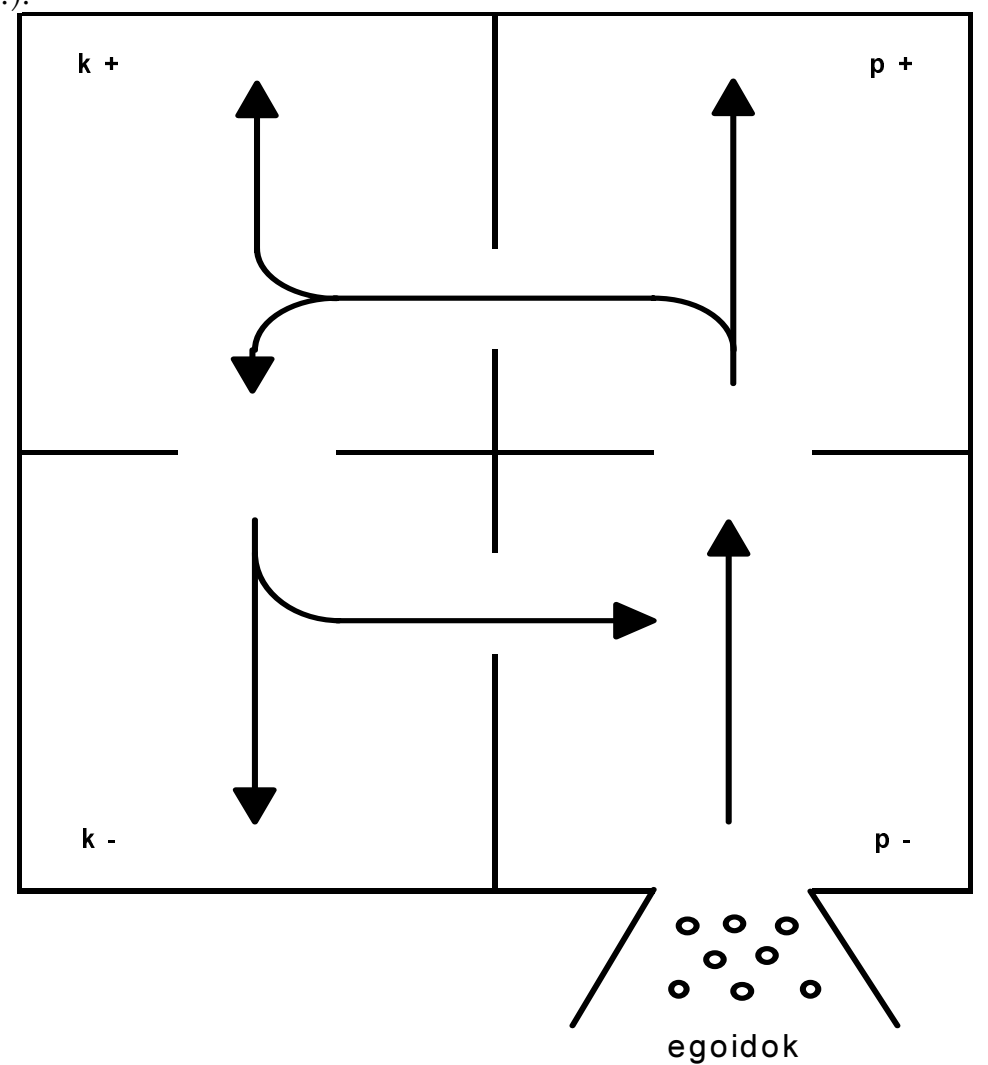

1. ábra. Az Én-működés sémája

\section{Az Én funkcionális müködése}

SZONDI az Én instanciájával, működésének leírásával a svájci pályaszakaszban részletesen Ich-Analyse című (1956) kötetében foglalkozott. Az énes ösztön Szondi pszichológiájában az egyedüli, eredetében is humán ösztön, ami azáltal tud a többi ösztön fölé emelkedni, hogy relatív autonómiával rendelkezik. Az Én azt tűzi ki feladatául, hogy a tudattalan ösztöncélokat tudatossá tegye, ezáltal olyan vezető szerepet tölt be, hogy a lélek középpontjába kerül. Az Én humánspecifikus funkciói a tudatosítás és az állásfoglalás. Az ösztönök vak kifuttatása helyett az ember képessé válik az érzelmek, indulatok, vágyak, vagyis a szükségletek tudatosítására, és a különböző, tudatosított ösztönszükségletek az Én állásfoglalását követelik. Az Énnek el kell döntenie, hogy mely szükségleteket hagy jóvá és járul hozzá ki- 
elégülésükhöz, és melyeket fog megtagadni. A jóváhagyás után az Énnek meg kell hoznia azt a döntést is, hogy a szükséglet kielégülését ősi, eredeti, natív formájában engedi kifuttatni, vagy a társadalmi alkalmazkodást szolgáló, szocializált formájú szükségletkielégítést engedélyezi. Csak az ember képes ösztöncéljai tudatosítására és arra, hogy individuálisan megválaszthassa ösztönszükségleteinek kielégítési módját. Éppen ezért az ember felelősséggel tartozik cselekedeteiért, amelyek már nem tudattalan irányítás alatt állnak, mint az állatvilágban. Az ember az Én funkciói segítségével a realitásérzék birtokába jut, képessé válik a valóságot felülvizsgálva tudatosan alkalmazkodni a külvilághoz. Az alkalmazkodási folyamat során és az önkontroll kialakításával az Én az ősi ösztönök kielégítési módját megváltoztathatja, denaturalizálhatja, amit Szondi az ösztönök szocializációjaként, humanizálásaként ír le, vagy más szavakkal az emberré válás folyamatának nevez.

A sorspszichológia szerint az Én négy elemi funkció állandó mozgásában ragadható meg, melyek a következők:

1. A participációs projekció, ami az ember azon törekvését fejezi ki, hogy más emberekkel eggyé váljon, egységet képezzen, duális unióba lépjen. A projekció révén az Én hatalmát kiterjeszti, ezek vezetnek a kettős vagy több tagból álló egységek kialakulásához az életben (például anya-gyermek egysége, a klánszolidaritás stb.). Az anya-gyermek duálunió felbomlása után az egyén a projekció segítségével más tárgy után néz, amellyel participálódhat, és amelyen ösztönszükségleteit kielégítheti. A participációs projekció következménye a pár, család, csoport, klán, népi és az egyéb társadalmi hovatartozás képződményeinek létrejötte.

A projekció mint a tartalom kivetítésének folyamata tágabb értelemben a külvilág, a világ megismerésének is alapja.

2. Az infláció az Én azon törekvése, hogy „mindenné váljon”, a teljességet érje el. Ez úgy valósulhat meg, hogy a tudattalan lelki tartalmak tudatosodnak és egyidejűleg az Én ezen lelki tartalmak ellentétességeit megszállja, ami által az Én megkettőzi hatalmát. Vagyis a mindkettő-és-minden-lenni-akarás, az ambitendencia Bleuer felfogásában. A személy lehet például egyidejűleg férfi és nö, ördög és angyal, úr és szolga, ember és állat stb. Pozitív esetben az infláció vezet az ideálképzéshez és teremti meg az erejét az alkotóképességnek, hogy a vallás, a művészet, a tudomány ideáit szenvedélyesen megszállhassuk.

3. Az introjekció az Én azon ősi törekvését írja le, hogy az értékes tárgyaknak, minden értéktartalomnak birtokosa legyen; vágy a mindent birtoklásra és a mindent tudásra. Az introjekció fiziológiai funkciója, hogy a külső és a belső érzékelési valóság között hidat teremtsen. Az introjekció segítségével jöhet létre az identifikáció (a külső érték beépítése a személyiségbe) és a karakterformálás.

4. A negáció az Én elemi törekvése az elkerülésre, a tagadásra, az elfojtásra. „A mindenné válni és mindent birtokolni” tagadása, elutasítása. Negatív értelemben az ideál- és értékképzés zavara, amely kétségbeeséshez vezethet. A negáció szociális értelmezése kettős jelentésü: egyrészt jelentheti a társas 
alkalmazkodás következtében történő lemondást, tagadást; másrészt pedig jelentheti a destrukciót. A negáció ereje Szondi tesztjében megmutatja, hogy adaptációval vagy destrukcióval állunk szemben.

A fenti négy elemi funkció ciklikusan követi egymást, ami azt jelenti, hogy egy tartalomnak - akár a külvilágból, akár a belső szükségleti tudat felól érkezik - a körfolyamat fenti négy fázisán keresztül kell haladnia. A lelki tartalom először a külvilágba kivetül (kielégüléséhez megfelelő tárgyat keres); ezután tudatosodik valamilyen kívánság, szükséglet, képzet, idea stb. formájában; majd az állásfoglaló én azt a realitással összeveti és dönt a tartalom igenléséről vagy elutasításáról.

Szondi az állásfoglalás képességét az Én erejének nevezi, ha hiányzik az állásfoglalás képessége, éngyenge személyről beszélünk. Az állásfoglaló Énnek köszönhetjük, hogy az ember képessé válik a szabad választásra, ezért ez egyben a szabad akarat kifejeződése a sorstanban. Az állásfoglaló Én működését az ábrán az introjekció és negáció folyamatai mutatják.

Az Ént akkor nevezhetjük integráltnak, vagyis akcióképesnek, ha egy felmerülő tartalom függetlenül annak minőségétől, a körpálya négy elemi funkcióján keresztülfut a megfelelő módon és megfelelő időben, anélkül, hogy egy fázisban túl sokáig időzne.

Szondi meghatározza az Én-fejlődés egyes szakaszaiban az általában vezető funkciót betöltő Én-funkciókat is. A participációs-projektív Én a kora gyermekkori preödipális időszakban jelenik meg és tart körülbelül 2 éves korig; az inflatív Én az ödipális kor kezdetén, 3-4 éves korban jelentkezik; az introjekciós Én az ödipális kor csúcspontján, 4-5 éves korban mutatkozik meg; a negációs Én az ödipális kor végén, a latencia és a prepubertás időszakában jelenik meg karakterisztikusan. Ezután az Én újból elkezdi körbefutni körpályáját a projekciótól a negációig (más tartalmakkal), ami a felnőttkori alkalmazkodás kialakulásának idejéig tart.

Pszichopatológiai szempontból a lelki zavar visszavezethető az Én körpályájának zavarára. A lelki zavar akkor jelentkezik, ha egy tartalom túl sokáig a körpálya egy bizonyos szakaszában „helyben jár”, vagy komolyabb probléma esetén egy bizonyos Én-funkció epizodikusan vagy tartósan a körpályáról tartósan kikapcsolódik. Ilyen Én-zavarok előfordulhatnak az Én primer hyper- vagy hypofunkciója következtében is, amelynek hátterében örökletes vagy fejlődési, illetve környezeti tényezők állhatnak.

Az egyes Én-funciók azonban még együttesen sem határozzák meg önmagukban az Én fenomenológiai megjelenését. A tudattalan Én-funkciók, a tudatos Én, az énkép, a felettes Én mind csak részfunkciói egy autonóm, globális énnek, amit Szondi Pontifex oppositorumnak nevezett el. Az örökletesség mellett a sorspszichológia középpontjában ez a Pontifex oppositorum áll, mely nemcsak az egyén, hanem az egyén által a közösség sorsát is alapvetően befolyásolja. 


\section{AZ ÉN MINT PONTIFEX OPPOSITORUM}

Szondi a lelki élet polaritását, az ellentétességet nemcsak belső pszichikus sajátosságnak tartja, hanem véleménye szerint a külvilággal való kapcsolatteremtés is ellentétességeken alapul. A legfontosabb lelki ellentétpárok a következők:

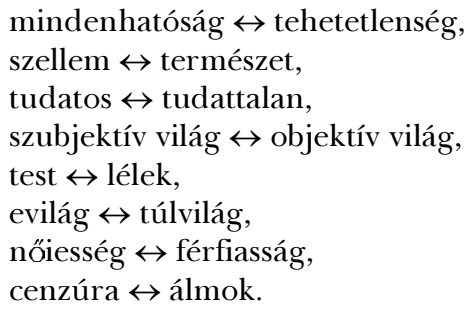

Az egyén élete csakúgy, mint az egész emberi fajé az ellentétek struktúrájára épül. Az ellentéteket, ellentmondásokat fel kell oldani. Kérdés azonban, hogy ezek az ellentmondások hogyan oldódnak fel, és ki (mi) által? Az ellentétességek kéttípusúak lehetnek: egymást kizáróak vagy egymást kiegészítőek, azaz komplementerek. A lelki ellentétességek majdnem összessége ez utóbbiak közé tartozik, az egymást kiegészítő ellentétességek két egymással ellentétes pólussal rendelkeznek. Az ideális megoldás az egyén számára az ellentétek feloldásában az integráció lenne, vagyis az ellentétességekből létrejövő egész újrateremtése. Ez lenne a legkedvezőbb megoldásmód mind az egyén, mind a környezet számára. Ha ugyanis az egyén azáltal oldja fel az ellentétességet, hogy az egyik pólust kiválasztva a másikat elutasítja, elfojtja, ez a megoldásmód a környezet számára sem lesz kedvező, mivel a személy maga veszélyt hordozó marad. Az egymást kizáró (nem komplementer) ellentétesség esetében csak az egyik oldal választható, ilyen például az élet választása a halállal szemben.

Az ellentétek feloldásának folyamatát egy magasabb instancia végzi a lélek központi irányításában, amit Szondi Pontifex oppositorumnak nevezett el. A Pontifex oppositorum feladata az ellentétek feloldásán túl a hatalomosztó, organizációs szerep betöltése, az ellentétek áthidalása, ami által létrejöhet az egészlegesség. A Pontifex-Én az ellentétes pólusok közötti hatalomosztó, organizátor és adminisztrátor a lélek tudatos és tudattalan tartományában egyaránt. A Pontifex-Én dönt az ösztöntermészet ellentétes törekvéseiben a szocializáció, szublimáció lehetőségéről, ami a szükségletek kielégítésének humánspecifikus, átszellemített feloldásmódját jelenti. A Pontifex-Én ebből kifolyólag sem nem szellem, sem nem természet, hanem híd a szellem és az ösztöntermészet között.

A Pontifex-Én áthidaló szerepét három funkció működése segíti, a transzcendencia, az integráció és a participáció. A transzcendencia képessége lehetőséget ad arra, hogy egyik területről átléphessünk egy másik területre; például a tudattalanból a tudatosba, a valóságból az absztraktba, a személyes síkból a személy fölöttibe. Az integráció a komplementer részfunkciók egyesítésének képessége, ami nyomán létrejöhet a lelki egészlegesség. Végül a participáció az újra-eggyé-válás lehetőségét adja, ami által az egyén részt vehet másokban (a mások iránt érzett szeretet- 
ben), a külvilágban (a kommunikáció folyamatában) és a szellemben (a hit révén).

Szondi nagy hangsúlyt fektet a hit szerepére. A hit az Én transzcendens képessége, az Én örök, misztikus participációját jelenti a szellemmel, ami során a mindenhatóságot az egyén továbbadja, ugyanakkor a participációs folyamatban részesedik is belőle oly mértékben, ami már az egyén számára is elviselhetővé válik. A szellemmel participálódó Én hagyja magát a szellem által vezettetni az irányítás és a hatalomosztás gyakorlásában, emellett azonban az átruházott hatalom egy részét visszakapja, ami azt jelenti, hogy személyes életvezetésének feladata és felelôssége nála marad.

Nem tisztáztuk még azt a kérdést, mit is jelent a „hatalomosztás” fogalma Szondinál. Az Én hatalomosztó funkciója képes kiválasztani a dolgok sokasága közül, hogy mi az, ami igazán fontos az egyénnek. Döntenie kell tehát az öröklött és ösztöntermészet, valamint a sorsot alakító olyan egyéb tényezők összefüggéseiben is, mint például a környezet, a szellem. Az egyén egészsége szempontjából döntő, hogy a hatalmat helyesen ossza szét ezek között a tényezők között, ami aztán egész sorsának alakulására is kihatással lesz. A Pontifex-Én - a saját egzisztencialehetőségeivel megbékélt, hittel rendelkező, integrált, a szellemmel participálódó Én - képes a sors humánspecifikus megvalósítására.

\section{A SORSANALÍZIS EMBERKÉPE}

A sorspszichológia leírta a kényszersors és a szabadon választott sors szerkezetét, amelyet a következő tényezők alakítanak:

I. A genetikus örökség, olyan ősi törekvések „mintáinak és figuráinak” öröksége, amelyek dinamikusan múködnek és élnek tovább a családi tudattalanban.

II. A specifikus ösztöntermészet, ami az örökletes talajból kialakult, megformált ösztönsajátosságokat jelenti.

III. A szociális környezet, amely adottságaival támogathatja vagy megakadályoztathatja az egyén lehetőségeinek kibontakoztatását.

$I V$. A mentális környezet, amely egyrészt a külső környezet korszellemét, világnézetét foglalja magába, másrészt azokat az intellektuális képességeket, amelyek befolyásolják az egyén sorsát.

$V$. Az Én, amely erejével, hatalmával, ideálképzeteivel kedvező esetben képes az öröklés során magunkkal hozott kényszersors, az ösztöntermészet, a szociális és mentális környezet korlátait áthágni.

VI. A szellem: az Én a szellemmel participálódva, általa megerősödve kivívhatja magának a szabadon választott sorsot.

A sorsanalízis leírja az ember életútjának azon lépcsőfokait, melyeket meg kell tennie ahhoz, hogy elérhesse az emberré válás legmagasabb fokát. Az emberré válás útja hat lépcsőfokból áll, melyek a mélylélektani irányzatok által feltárt emberképek egymásra épülő soraként is leírhatók. 
A 0 fázis a homo participátorként fogható fel, ami az első életévben az anyával duálunióban élő emberi lényt ábrázolja. Az $A$ fázis a homo represszor fázisa, ami a 3-4 éves ödipális korban jelentkezik és jellemzője az elfojtás. Freud pszichoanalízisében ebben a periódusban jelentkezik minden primér elfojtás, ami később a neurózis alapjául szolgál. A homo repressor emberré válása a szublimáció útján történik. A $B$ fázis a homo potentatort mutatja, aki kisebbrendűségi érzését úgy kompenzálja, hogy hatalomra törekszik. Ez a periódus a pre- és posztpubertás idején jelentkezik. E problematikát individuálpszichológiájában Adler írja le. A C fázisban a homo individuátor az individuáció folyamatában megvalósítja egyszeri önmagát. Leginkább az emberi élet negyedik, ötödik évtizede az időpontja, a folyamattal Jung analitikus pszichológiája foglalkozik. A $D$ fázis a sorsanalízis homo electorát mutatja, azt az embert, aki tudatára ébredt magával hozott létlehetőségeinek, és saját sorsát meghatározva választ foglalkozást, szerelmet, világnézetet, vallást. A homo elector legfontosabb időszakai a 20-30 év (foglalkozásválasztás), 30-40 év (házastárs megválasztása) és 40. év után (világnézet megválasztása). Az E fázist a homo liberator et humanizator képviseli, Maeder vallásos-humanisztikus irányzata, az az ember, aki képessé válik a felebaráti szeretetre, hogy kiterjessze szeretetét a saját énről a családra, a saját családról más családra, a saját vallás tagjairól más vallás tagjaira, a saját szociális osztályról más szociális osztályokra, a saját rasszról a világ más rasszaira (SZONDI, 1996). Az emberré válás útjának sémáját mutatja be a 2. ábra.

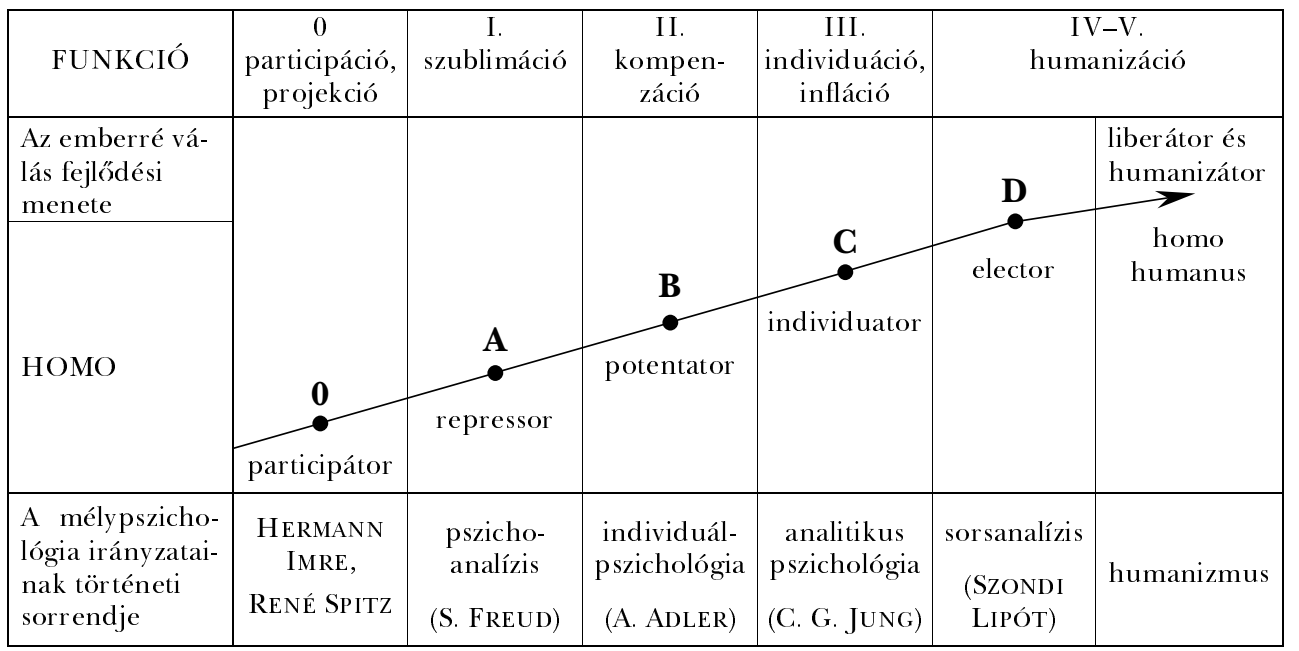

2. ábra. Az emberré válás útja

Az emberré válás útja mindig nyitva áll az egyén elött. Az egyén ezen az úton azonban akkor juthat elôrébb, ha a sokféle létlehetőség közül a humanizált útirányt képes önmagában tudatosítani, majd ezt követően szabadon választani. 
A sorsanalízis gyakorlata is e szemlélethez kötődik. Az első lépés a terápiában az ellentétességek tudatosítása, a második ezen ellentétességek a személynek önmagára történő elismerése, majd a harmadik lépés az ellentétességek feloldása, ahol a vagy-vagy típusú választás helyébe a mind... mind típusú lép. Ez az emberek többségénél szinte keresztülvihetetlennek tűnik, ennek ellenére az egyén számára az emberré válás útja nyitva áll, s ha minden erejével törekszik erre, napról napra előrébb haladhat a humanizáció útján.

\section{A SORSANALÍZIS - MAI SZEMMEL}

Szondi sorsanalízisének értékelésekor számos körülményt figyelembe kell vennünk, mindenekelőtt a két világháború közötti, század eleji korszellemet, amelyben e tan megszületett.

A pszichológia területén belül Szondi sorsanalízisére elsődlegesen Freud pszichoanalízise gyakorolt hatást. Szondi a freudi felfedezésre, a tudattalanra építette saját elméletét, amit maga is úgy nevezett, mint „a genetika bevezetését a pszichoanalízisbe”. A század első felében megjelenő mélylélektani irányzatok - Freud, Jung, Adler és Szondi pszichológiája is - elméletük megalapozására a természettudomány, elsősorban a biológia ismerettárát és eszköztárát igyekeztek felhasználni. Szondi a genetikára építette elméletét. A genetikai megközelítés Szondinál az értelmi fogyatékos gyermekek vizsgálatából származik. Kórtani és Gyógytani Laboratóriumában Szondi az értelmi fogyatékos gyermekek „egészleges vizsgálatát” tűzte ki célul, ami azt jelenti, hogy a fogyatékosság örökléstani, élettani és szociális körülményeire egyaránt kiterjedt a figyelme. A nagyothallás és egyéb fogyatékosságok örökletes sajátosságai kapcsán követte a korabeli kiemelkedő színvonalú, elsősorban német, de az európai genetikusok publikációit is (mint például Brugger, Verschauer, Luxenburger, Sarbo, Schulz, Weinberg és Rüdin, Lundborg, Johannsen, Bauer, Aschner, Csörsz Károly stb. Lásd SzondI, 1935, 1936), amit saját örökléstani vizsgálataival egészített ki. Az örökléstani tényezők rögzítése céljából tervezte egy ún. családi regiszter létrehozását, amiben tervei szerint minden fogyatékos gyermek családfája leírásra került volna. A családfavizsgálatok nyomán született meg a kísérleti ösztöndiagnosztikai teszt (mai elnevezésében Szondi-teszt), mely kezdetben a genoteszt nevet kapta. A családfa kikérdezése ugyanis túl sok idôt vett igénybe, sokszor a rokonok adatairól szóló ismeretek sem voltak pontosak. Szükség volt tehát egy olyan tesztre, amely megmutatja, hogy - Szondi elnevezésében - a probandus milyen öröklött ösztönadottságokkal rendelkezik. Szondi tesztjét eredetileg génbiológiai és nem lélektani célokra szánta, olyan kísérleti módszert keresett, melyeknek segítségével megállapítható, hogy az egyén milyen specifikus géneknek, milyen sajátos családi hajlamoknak az átvivője, konduktora. Miközben a kísérleti családkutatás és a specifikus génkonduktorság kísérleti megállapításának módszerét kereste, a családi tudattalan feltárásához jutott el.

Ezen a ponton érdemes SzONDI visszaemlékezését (1943a, 1-2) idéznünk, aki elméletének és tesztjének megszületéséről így nyilatkozik: „A kísérleti ösztöndiagnosz- 
tika a pszichodiagnosztikának új hajtása. Új benne az, hogy az ember ösztönéletét kísérleti úton, nem pedig élmények elbeszélésével és szabad képzettársítások elemzése útján kívánja megismerni. Arra vállalkozik, hogy experimentálisan, minden hozzáértö számára láthatóvá tegye az ember ki nem elégített és éppen ezért dinamikus ösztönigényeit. Alkalmazása a mélylélektan és nem a mentális pszichológia területére esik. A kísérleti ösztöndiagnosztika az ember sorsát veszélyeztetö, lappangó ösztönigényeket teszi láthatóvá... Alkalmazása azonban túlmegy az egyszerü diagnosztika célkitüzésén. Mert, amikor a mélylélek veszélyes ösztönigényeit leleplezi, akkor egyben a lelki megelözésnek és lelki egészségvédelemnek is egyik útmutató eszközévé válik. A kísérleti ösztöndiagnosztika a már megnyilatkozott (manifesztálódott) és a ki nem elégített (latens) ösztöntörekvések kölcsönös kapcsolatát, ennek a kapcsolatnak egyénileg finoman elkülönithetö változatait is felfedi... A kisérleti ösztöndiagnosztika két részböl áll. Elöször: magából a kísérleti módszerböl, melyet genotesztnek neveztem el; másodszor a sorsanalitikus ösztöntanból és az arra épitett sorsanalitikus lélektanból. Bár a genoteszt mint ösztönkutató módszer, célkitüzésében, úgy tudom, ma még talán egyedül áll a kisérleti lélektanban, bevallom, magam fontosabbnak tartom a sorsanalitikus ösztöntant. Úgy vélem ugyanis, hogy az ösztöntan a kisérleti módszertöl függetlenül is biztosan áll a talpán. A genoteszt ellenben a sorsanalitikus ösztöntannak csak egyik származéka, csak egyik módszere. Ösztönrendszeremet nem a genotesztböl vezettem le, hanem forditva történt: a genoteszt a sorsanalizisnek már in toto kész, génbiológiai ösztönrendszeréböl nött ki."

A genoteszt müködése az arcképek felszólító jellegére épül, Szondi itt LEWIN (1926) gondolatát alkalmazza a tárgyak felszólító jellegére vonatkozóan. A tesztre alkalmazva a felszólító jelleg a következőt jelenti: annak az arcképnek lesz a társítások kapcsán felszólító jellege és így pszichodiagnosztikai értéke a legnagyobb, mely arckép azt az ösztönszükségletet képviseli, amelyik a vizsgált személyben örökléstanilag és aktuálisan a legnagyobb dinamikus erővel él. A tesztben felhasznált arcképeknek specifikus felszólító jellegük van, melyek oly élő vagy valaha élt emberekről nyert emléknyomokat, azokkal átélt élményeket idéznek fel a vizsgált személyben, melyek a múltban vagy a jelenben is genotropisztikusan hatnak az egyénre. Az arcképek a genotropisztikus hatást idézik fel az egyénben, a megfelelő engrammot aktiválják - itt elfogadja SEMON (1904) álláspontját Szondi, miszerint az organikus anyagnak is van emlékezete -, és az újonnan felidézett emlékkép irányítja a választást az élettelen arcképek között is.

Az örökléstan, a genetika befolyása a sorsanalízis elméletére nézve nyilvánvaló. A genetika a 20. század dinamikusan fejlődő tudományága, a század eleji tapogatózó vizsgálatoktól a század végére eljutottunk az élő szervezetek klónozásáig, a közeljövő célkitűzése az ember teljes géntérképének az elkészítése. A genetika mai állása számos ponton nem igazolja Szondi elképzeléseit például az ösztöngének, az egoidok feltételezésében; vagy archaikusak az olyan kifejezések is, mint például az ősök várócsarnoka, illetve a pórul járt ősök tömlöce; mégis, ha e fogalomtárt metaforikusan kezeljük, lassan eljön az ideje, hogy a tudomány képessé váljon arra, hogy igazolja vagy cáfolja a Szondi által leírt jelenségek valódi örökléstani hátterét (vö. BERECZKEI, 1993; VARGHA, 1994).

A pszichoanalízis is több fordulatot megélt már a freudi ösztön eredetű énfogalom meghatározása óta. A sorsanalízis Freudhoz hasonlóan az én ösztöneredetére épít, de Szondi Hartmannal párhuzamosan egyidőben az ént állítja a 
középpontba és leírja az én veleszületett funkcióit (én-tágító és én-szűkítő funkciók: a projekció, infláció, introjekció, negáció múködése révén; illetve az állásfoglaló Én humánspecifikus funkciója). Freud felfogásától többek között abban is különbözik Szondié, hogy Szondinál az én eredete egy humánspecifikus ösztönre, az énes ösztönre vezethetô vissza. A pszichoanalízis ösztöntani dualizmusát elveti Szondi és helyette négy alapösztönt feltételez...

A sorsanalízis elméletében megjelenik az ember természettudományos és szellemtudományos megközelítésének kettőssége, amit maga Szondi is érez, és próbát tesz arra, hogy feloldja ezen ellentétességet. A sorspszichológia természettudományos megalapozásában a már említett genetikáé a döntő szerep, SzONDI e szemléletből fakadóan a genotropizmus fogalmát a sejtbiológiai osztódási folyamatig vezeti vissza, melyet Módszertan és ösztöntan címü (1943a, 315-321) kötetében sejtbiológiai ábrákon is bemutat.

Szondi a lélek Én-instanciáján keresztül ugyanakkor az embert a szellemhez is köti. Kifejti, hogy a szellem és az Én, a szellem és az ösztön kapcsolatait sosem értheti meg az, aki a humanizmus és az ösztön, a humanizmus és az Én kapcsolatait nem látja tisztán (SZONDI, 1943c, 12-14). A „humánus”, az emberiességre való törekvés Szondinál azt jelenti, hogy az állatvilág fölé emelkedve a homo sapiens képessé válik ősi ösztönszükségleteit „emberi” módon kielégíteni. A humanizálódás (emberré válás) feltétele a bennünk élő ösztönerők ellentétességének tudatosítása; majd annak elfogadása, hogy lehetetlen feladat lenne az egyik ösztönerő teljes kiirtása és a másik választása, vagyis az embernek rá kell eszmélnie, hogy humán szerepét csak akkor tudja betölteni, ha az ellentétes ösztönerő mindkét pólusát valamilyen módon kielégíti: választva a natív, természetes kielégítésmód és a szublimált forma között. A sorspszichológiában az Én lesz az az instancia, amely dönt az adott ösztönszükségletek natív vagy szublimált formájú kielégítése mellett. Vagyis az Én az az „X-instancia”, amit a metafizika szellemnek nevez, s amelynek tesztológiai nyomait Szondi kísérleti ösztöndiagnosztikájában leírta. A tesztológiai jelek értelmezését összefoglalva a „szellem” megjelenésére utal a biszexualitásról, az erőszakosságról és általában az érzékiségről történő lemondás, ami a gyöngédség és önátadás kiterjesztését teszi lehetővé minden emberre; a düh, harag, bosszú és gyưlölet helyett a karitatív, másokon segíteni akarás érvényesülése; és végül a bigámia, poligámia és biszexuális kötődés helyett az egy tárgyhoz történő tapadás, egy tárgyba történő belekapaszkodás jelenik meg és az egyén azon képessége, hogy önzetlenül lemondjon arról, hogy új örömtárgyak után szaladjon.

A humanizmus Szondi értelmezésében ösztöntanilag azt jelenti, hogy az egyén gyöngédségét (h-faktor) és önátadását (,s-”) minden emberre ki tudja terjeszteni (,p+”) a családi, nemzeti, faji határokat átlépve. Az emberré válás útjának az emberré válás eszméje szab irányt, mely eszme Szondi szerint nem lehet más, mint „a szeretet kiterjesztése". Ezen a ponton Szondi a kereszténység tana mellett foglal állást, miszerint „, a felebaráti szeretet gondolata nem illúzió, hanem az ember saját, emberré válásába vetett hite" (SZONDI, 1996, 122).

A sorsanalízisben a hitfunkció (nemcsak vallásos értelemben vett) szerepét a következóképpen írja le SzONDI: „Anankológiánkban azt a felfogást valljuk, hogy a jö̀öre irányuló hitfunkció egyfajta énfunkció, amely az egyén feletti, nem materiális szellem 
tartalmával, ideáival van feltöltve. Az én hitfunkciója sorsépitö, mivel az mint híd funkcionál az emberfeletti szellem és az összemberi öröklött és ösztöntermészet között. Csak egyedül a hitfunkcióval sikerül az énnek az embert a jövö lidércnyomásától megszabadítania, s abból jövőbeli létet épiteni. Csak a hitfunkció alkalmas arra, hogy az embert öröklött és ösztönsorsával megbékitse. Ez az emberré válás előfeltétele” (1996, 35).

A természettudományos genetikai megalapozottságától ekképp ível a sorsanalízis a szellemtudományok, sốt a keresztény hit ideológiájáig.

Szondi sorsanalízisének tudománytörténeti jelentőségét röviden úgy összegezhetnénk, hogy egyrészt a tudattalan családi rétegének és funkciójának leírásával új paradigmát hozott a mélypszichológiai irányzatokban; másrészt terápiás technikájával képessé vált az un. „öröklött neurózisok”, prepszichózisok kezelésére; vagyis ezáltal olyan lelki betegségek gyógyítására nyílt lehetőség, melyek nem traumatikus eredetüek, hanem örökletes hátterüek. Szondi intuitív empirikus elmélete saját korát messze megelőzte - és a humángenetika, a szociobiológia, a modern pszichológia igazából most jut el arra a fejlettségi fokra, hogy igazolhassa avagy pontosíthassa Szondi tanait (lásd BERECZKEI, 1999, illetve jelen folyóiratszámban).

Szondi elméleti hagyatékát mindenképpen érdemes lenne újból megismerni és továbbgondolni a mai pszichológiai élet több területén is, például a mai egészségpszichológia bio-pszichoszociális modelljében, amely szemléletében - az egyén életére ható különböző tényezők integratív felfogásában - nem is áll olyan messze Szondiétól; vagy a különböző alkalmazási területek potenciális lehetőségeiben a hagyományos klinikai pszichológiai alkalmazáson túl (például a pszichiátriai felfogásban teljesen új szemléletet hozhatna Szondi Én-hasadási elmélete!) többek között a tanácsadás, a prevenció, a neveléslélektan, az alkalmassági vizsgálatok szerteágazó területein.

\section{IRODALOM}

Bereczkei T. (1993) Biológiai evolúció, genotropizmus, pszichopatológia. A Szondi-elmélet újraértelmezése. Thalassa, 4, 150-172.

Bereczke i T. (1999) Szondi és a modern biológia. In Gyöngyösiné Kiss Enikő (szerk.) Szondi Lipót. 158-165. Új Mandátum Könyvkiadó, Budapest

Freud, S. (1981) A befejezett és a vég nélküli analízis. >csonka fordítás@n Buda Béla (szerk.) Pszichoterápia. 84-98. Gondolat Könyvkiadó, Budapest

Freud, S. (1982) A pszichoanalízis foglalata. In Freud, S. Esszék. 407-474. Gondolat Könyvkiadó, Budapest

Freud, S. (1986) Bevezetés a pszichoanalizisbe. Gondolat Könyvkiadó, Budapest

GyönGyösınÉ KISS E. (1999) (szerk.) Szondi Lipót. Új Mandátum Könyvkiadó, Budapest

GyÖNGYÖSINÉ KISS, E. (1995) Schicksal-Analysis and Jewish Faith. Szondiana, 15, 27-34.

HARTMANn, H. (1939) Ich-Psychologie und Anpassungsproblem. Klett, Stuttgart

Hartmann, Kris és Loewenstein The Psychoanalitic Study of Child címü folyóirat 1947, 1949, 1950, 1952, 1955. évi számaiban megjelent munkái 
Lewin, K. (1926) Vorsatz, Wille und Bedürfnis. Springer Verlag, Berlin

LukÁCS, D. (1996) Szondi. Az ösztönprofiltól az elméletig. Animula Kiadó, Budapest

Semon, R. (1904) Die Mneme als erhaltendes Prinzip im Wechsel des organischen Geschehens. Engelmann, Leipzig

Szondi L. (1935) A családkutatás és ikerkutatás módszertani elemei. Árpád Részvénytársaság Könyvnyomdája, Kalocsa

SzONDi L. (1936) Az örökléstan jelentösége a gyakorlatban. Különlenyomat a Thearpia márciusi számából

SzOndi L. (1937) Analysis of marriages. An attempt at a theory of choice in love. Acta Psychologica. III. Martinus Nijhoff, Hága

Szondi L. (1939) Elöadások a kisérleti ösztöndiagnosztika köréböl. Elmélet és methodika. Diószegi sokszorosítás, Budapest

SzONDI L. (1942) Elöadások a kísérleti ösztöndiagnosztika köréböl. IV. kötet. Az ember meghatározása az ösztönök tapasztalati rendszerében. Az ember ösztön-Linnaeusa. Diószegi sokszorosítás, Budapest

SzONDi L. (1943a) Elöadások a kísérleti ösztöndiagnosztika köréböl. I. kötet. Módszertan és ösztöntan. Diószegi sokszorosítás, Budapest

SzONDi L. (1943b) Előadások a kísérleti ösztöndiagnosztika köréböl. II. kötet. Módszertan, általános ösztöntan és tünettan. Kiadatlan kézirat

SzONDi L. (1943c) Elöadások a kísérleti ösztöndiagnosztika köréból. III. kötet. Az én kísérleti elemzése. Diószegi sokszorosítás, Budapest

Szondi L. (1944) Schiksalsanalyse. Wahl in der Liebe, Freundschaft, Beruf, Krankheit und Tod. Schwabe et Co., I. kiadás, 1944; II. kiadás, 1948; III. kiadás, 1964; Basel

Szondi L. (1952) Triebpathologie „A” és „B” kötetei. Verlag Hans Huber, Bern

SzOndi L. (1956) Ich-Analyse. Hans Huber, Bern und Stuttgart

SzONDi L. (1960) Lehrbuch der experimentellen Triebdiagnostik. Verlag Hans Huber, Bern

SzONDi L. (1963) Schicksalsanalytische Therapie. Ein Lehrbuch der passiven und aktiven analytischen Psychotherapie. Hans Huber, Bern und Stuttgart

SzONDi L. (1996) Ember és sors. Három tanulmány. Összeállította és az utószót írta: Gyöngyösiné Kiss Enikő. Kossuth Könyvkiadó, Budapest

Szondi L. (1999) Sorsanalízis és önvallomás. In Gyöngyösiné Kiss Enikő, Szondi Lipót. 4165. Új Mandátum Könyvkiadó, Budapest

VARGHA A. (1994) A Szondi-teszt pszichometriája. Universitas, Budapest

\section{FATE-ANALYSIS OF LEOPOLD SZONDI}

\section{GYÖNGYÖSINÉ KISS, ENIKŐ}

Szondi was a Hungarian psychiatrist, who created his theory and his method from 1937 to 1944, in Hungary. World War II interrupted his work, he had to leave the country. Finally, after the war he settled in Zürich. 
Szondi considered his fate-analysis as belonging to depth psychology, and he thought that it could be a contact between Freud and Jung. Szondi supposed, that between the personal and collective unconscious there is a third: and this is the familial unconscious. This familial unconscious is originally based on genealogy. The decendent gets his genetic structure from his ancestors which determines the possibilities of his life and fate. Consequently the goal of fate-analysis is the scientific investigation of human destiny.

This study deals with the most important expressions and the view of the fate-analytical theory.

Key words: $\quad$ a new concept of fate, the drive-system of fate-analysis, the fate-analytical interpretation of ego, the road to becoming human 